\title{
ADDITIONAL NOTES ON \\ STEPHANITIS TAKEYAI IN NEW ENGLAND \\ (HETEROPTERA: TINGIDAE)
}

\author{
By Norman S. Bailley
}

Kingston, New Hampshire $03848^{*}$

In 1950 I reported this Asiatic lace bug as a serious pest of Pieris japonica (Thunberg) Don in Greenwich, Connecticut, and the surrounding area. Since 1956 I have been teaching at Bradford College, in northeastern Massachusetts. Although there are several specimens of Pieris on the rather nicely landscaped campus and in the planting around a college house I lived in for many years, I saw no evidence of lace bugs until the fall of 1973. On that occasion I searched the plants showing considerable injury but failed to find any tingids.

On September 9, 1974, however, I noted that the same plants showed typical signs of severe feeding injury and found numerous nymphs and adults of Stephanitis takeyai on the undersides of the leaves of two Japanese Andromedas. ${ }^{1}$ These plants grow in a mixed shrub planting along the north foundation of our main lecture hall. In the same foundation planting are such other evergreen ericaceous shrubs as Pieris floribunda Bentham \& Hooker, Rhododendron carolinianum Rehder, Kalmia latifolia L., Leucothoë catesbaei Gray, and a few deciduous azaleas. With the exception of an azalea, whose branches intermingle with one of the infested Pieris japonica, there was no evidence of lace bug feeding nor did I find any tingids on the other ericaceous plants. This particular azalea, which may be $R$. calendulaceum Torrey, does show lace bug injury and specimens were collected from it. Many of its leaves had also been almost skeletonized in a way that suggested Japanese beetle damage.

A few days later I found another heavily infested Pieris japonica in a planting near a small building towards the south end of the campus. This suggested checking further. On October Ist, two more plants were found on the front campus with tingids present in some

*Address after July 1, 1975: Mohler Laboratory, Swans Island Marine Station, Swans Island, Maine 04685.

${ }^{1}$ The original name of this species, globulifera Matsumura, turns out to be a junior homonym, and it was renamed takeyai by Drake and Maa, 1955. See also Drake and Ruhoff, 1965.

Manuscript received by the editor November 2, 1974. 
numbers. One grows on the north corner of our auditorium and the other on the west side of the same building. The latter grows beside a hybrid Rhododendron that also showed considerable leaf discoloration, especially on leaves of the previous year. This year's growth was only thinly specked with fine whitish dots on the upper surface and no lace bugs were located on either the older or the newer foliage of this plant.

On October 3rd I extended the search and inspected Pieris japonica specimens in the front foundation plantings of five college owned houses situated on the opposite sides of the two streets that parallel the east and the west sides of the main campus. A sixth house is on a road beyond the tennis courts at the southern edge of the college property and about a half a mile from the front of the campus where specimens were first found. All of the plants observed showed some evidence of injury and several were heavily infested. In spite of light frosts on at least two nights recently, temperatures below $40^{\circ} \mathrm{F}$ for another two nights, and only in the low fifties during the two consecutive days, adults (some teneral) and nymphs of Stephanitis were numerous and active on some of these Pieris on October 3 rd and 4 th.

On the $4^{\text {th }}$ a collection was taken from a Pieris japonica by the northeast entrance to the campus. This plant had numerous nymphs and some adults on the leaves. At least four nymphal instars are represented in this one late season collection. The smallest nymph, without apparent spines, was $0.7 \mathrm{~mm}$. long. Others measured I.2 $\mathrm{mm}$., $\mathrm{r} .8 \mathrm{~mm}$. and $2.4 \mathrm{~mm}$. in length and these all had prominent spines on the dorsal side of head, thorax, and abdomen Three adults found with them measured from 3.9 to $4.2 \mathrm{~mm}$.

Although many leaves were examined (several with the aid of a stereoscopic microscope), no evidence of eggs was discovered. Therefore, the late occurrence of early nymphal instars and of teneral adults strongly indicates that $S$. takeyai may over-winter in these stages, contrary to my earlier suggestion (195I). Obviously this point needs clarification. ${ }^{2}$

On October 26th, specimens of Pieris japonica showing characteristic discoloration were seen in Haverhill at least two miles from the

\footnotetext{
${ }^{2}$ While this paper was in press, I received a copy of Dr. Dennis Dunbar's recent (1974) article on this tingid, in which mention is made of the general occurrence of takeyai in southern New England, without giving specific localities in Massachusetts. The same paper provides a full account of the life history in Connecticut and indicates the species lays eggs that overwinter in the Pieris leaves there.
} 
campus and north of the Merrimac River. The campus is in a residential area south of the river. Obviously this lace bug is now well established locally. The leaves of Pieris japonica, much discolored and damaged by the heavy feeding of Stephanitis, tend to drop prematurely. Consequently, gardeners and nurserymen should be concerned with the spread of this lace bug from southwestern Connecticut into northeastern Massachusetts.

\section{REFERENCES}

BAILEX, L. H.

1949. Manual of Cultivated Plants. Macmillan Co. New York. Bailex, Norman S.

1950. An Asiatic Tingid New to North America (Heteroptera). Psyche $57: 143-145$.

1951. The Tingoidea of New England and Their Biology. Ent. Americana 31 (n.s.) :53-62.

Drake, C. J. ANd T. MaA

1955. Chinese and Other Oriental Tingoidea (Hemiptera). Part III. Quart. Journ. Museum Taiwan 8:1-11.

Drake, C. J. and F. A. Ruhoff

1965. Lace Bugs of the World: A Catalogue. U.S. Nat. Mus. Bull. $213: 364$.

Dunbar, Dennis M.

1974. Bionomics of the Andromeda Lace Bug, Stephanitis takeyai. Mem. Conn. Ent. Soc. 1974 :277-289. 

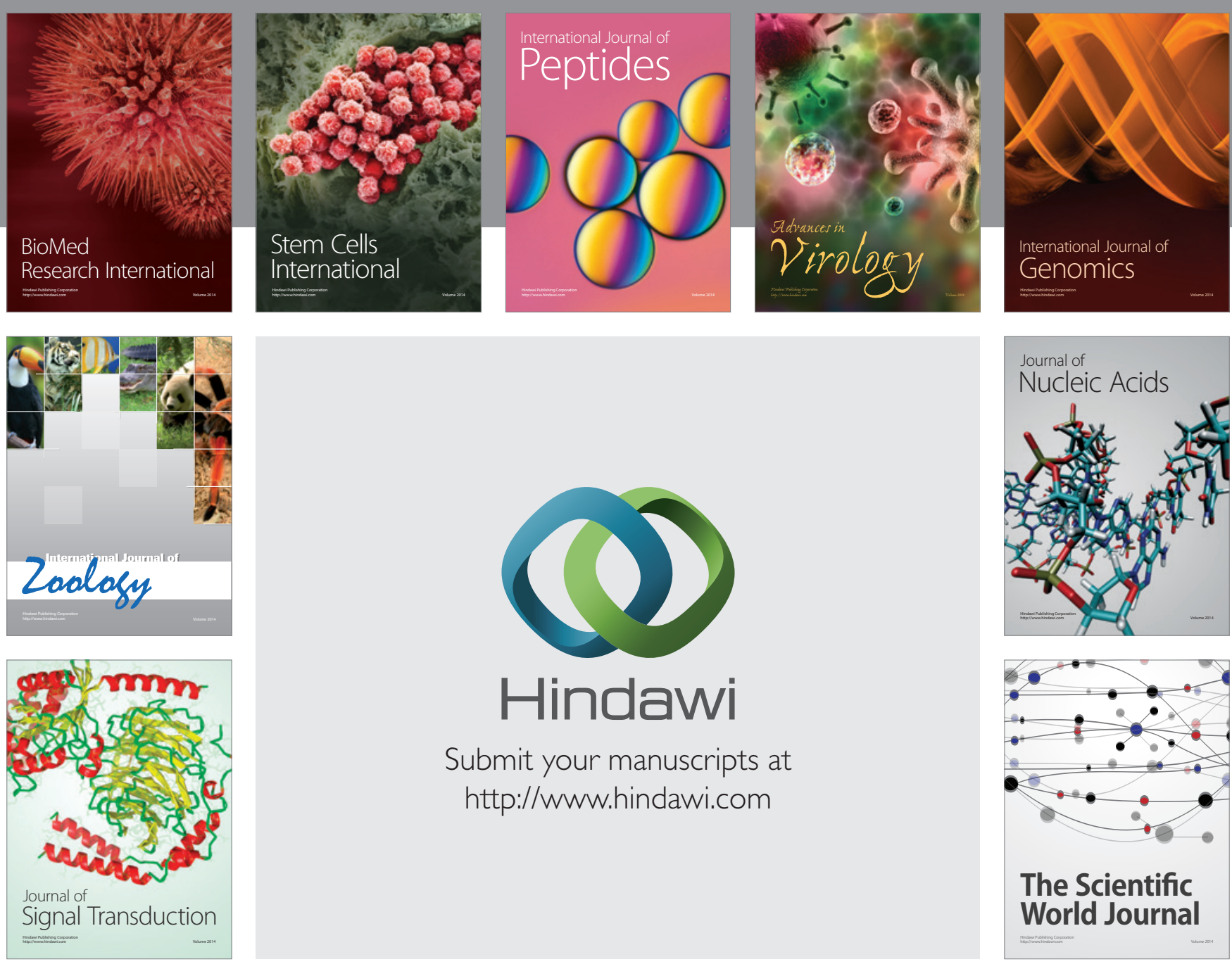

Submit your manuscripts at

http://www.hindawi.com
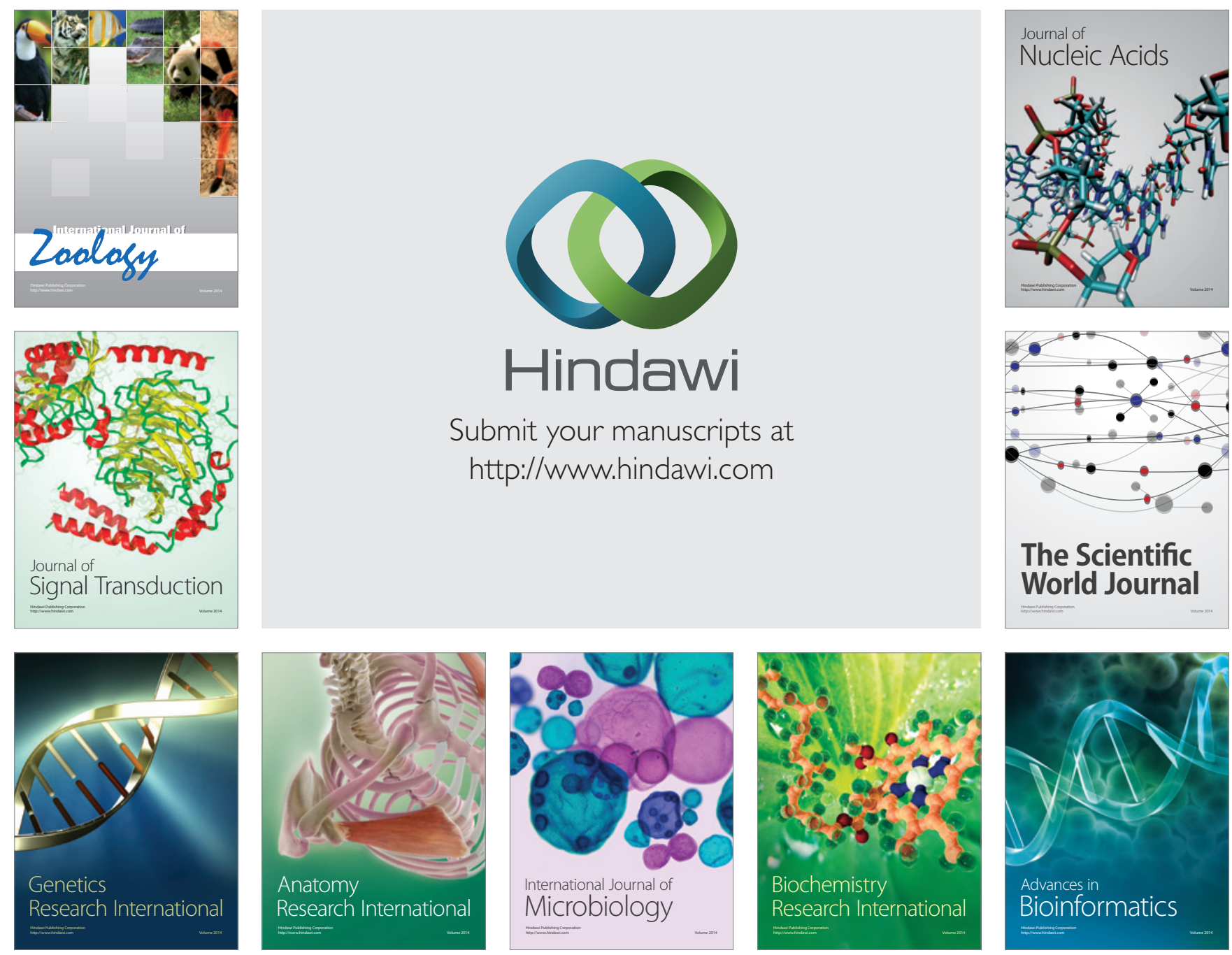

The Scientific World Journal
